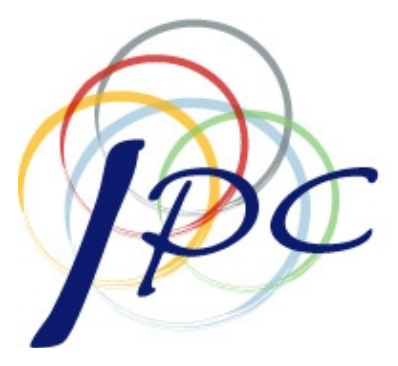

INTERNATIONAL Policy CENTER Gerald R. Ford School of Public Policy University of Michigan

IPC Working Paper Series Number 119

Labor Standards and Human Rights: Implications for International Trade and Investment

Drusilla K. Brown

Alan V. Deardorff

Robert M. Stern

August 19, 2011 


\title{
Labor Standards and Human Rights: Implications for International Trade and Investment
}

\author{
Drusilla K. Brown, Tufts University \\ Alan V. Deardorff, University of Michigan \\ Robert M. Stern, University of Michigan and UC-Berkeley
}

\begin{abstract}
The establishment of international labor standards linked to market access within the WTO is among the proposals intended to remedy the gross violations of labor and human rights that accompany international trade and investment. Yet, the WTO Charter and, previously, the GATT are virtually silent on the potential inhumanity of globally integrated goods and services markets. Despite intense pressure from the United States and the European Union, the Singapore Ministerial Declaration (December 1996), while acknowledging the importance of international labor standards, identified the International Labor Organization (ILO) as the competent body to establish and monitor labor standards. However, advocates for international labor standards ultimately gained access to the process of rules-setting in the WTO indirectly through Article XXIV governing the creation of customs unions and free trade agreements and, more importantly, the 1971 GSP Decision permitting special and differential treatment of developing country exports.
\end{abstract}

Thus, contrary to the WTO Ministerial dictates, labor standards are now routinely enforced by the prospective loss of preferential tariff concessions and market access. We discuss in this context a mechanism for linking ILO-established labor standards, monitoring by the ILO, and enforcement through the threat of lost trade concessions that emerged fully operational in the 1999 U.S.-Cambodia Bilateral Textile Trade Agreement. Under this agreement, the United States provided Cambodia access to US markets by giving expanded apparel and textile quotas conditional on improved working conditions in the garment sector.

We also discuss the labor and human-rights issues that emerge in a globalizing world economy, the market failures that produce labor and human-rights violations, and the role of labor standards in mitigating the most grievous of consequences. We then discuss the evidence on the impact that labor standards have on trade, firm behavior and investment, and on workers, and whether or not there is a race to the bottom, which we conclude not to be the case.

JEL Codes: F1, F10, F13

Keywords: International Labor Standards; ILO; WTO; Effects on Trade and Investment

August 19, 2011

Address correspondence to:

Robert M. Stern

rmstern@umich.edu

rms@berkeley.edu 


\section{Introduction ${ }^{1}$}

The integration of global goods and services markets facilitated first by the General Agreement on Tariffs and Trade (GATT) and subsequently by the World Trade Organization (WTO) is correlated with economic prosperity and a fall in poverty according to Harrison (2007).

Nevertheless, news of labor and human-rights violations in global-supply chains abound.

Violations of the most egregious sort such as human trafficking, child enslavement, mortally hazardous conditions of work, verbal and physical abuse, exhausting hours of work, nonpayment of wages, etc. are common occurrences (see National Labor Committee, 2006).

The establishment of international labor standards linked to market access within the WTO is among the proposals intended to remedy the gross violations of labor and human rights that accompany international trade and investment. Yet, the WTO Charter and, previously, the GATT are virtually silent on the potential inhumanity of globally integrated goods and services markets. The only labor standard currently in the WTO Charter is embedded in Article XX(e), permitting member nations to prohibit imports of goods produced by prison labor. ${ }^{2}$

Following the failure of the International Trade Organization (ITO) which covered labor standards, the international harmonization of labor standards was removed to the United Nations, even though the International Labor Organization, which had been established in 1919, was designed for this purpose. The Universal Declaration of Human Rights of 1948 was adopted by the U.N. General Assembly without dissent. As noted in OECD (1996), the Declaration provides

\footnotetext{
${ }^{1}$ What follows in this chapter has been adapted in part from Brown (2011) and Brown and Stern (2007). We are indebted to Andrew Brown, Kimberly Ann Elliott, Ana Frischtak, and David Kucera for helpful comments on an earlier version of the chapter. Elliott (2011) covers many issues related to this chapter.

${ }^{2}$ Cross-country harmonization of labor-market regulations was first advanced by Switzerland in 1881, as noted in Engerman (2003). Following a series of international conferences, several west European countries agreed to ban international trade in white-phosphorous matches and place limits on night work for women. Article 7 of the 1948 Havana Charter established a 'Fair Labor Standards' clause and was to be included in the charter of the moribund International Trade Organization (ITO). However, only the general exceptions provisions limiting trade in goods produced by prison labor (Article XX(e)) survived into the GATT.
} 
for: "civil and political rights (the right to life, liberty, freedom from torture, freedom of opinion and expression, freedom from slavery and servitude, right to peaceful assembly and association) and economic, social and cultural rights (right to join and form trade unions, right to work, right to equal pay for equal work, right to education).”3

Further coordination of labor laws within the multilateral system was proposed by the European Parliament in 1983 and 1994, by the U.S. government in 1986 and at every WTO Ministerial between 1996 and 2001. Despite intense pressure from the United States and the European Union, as Stern (2003) notes, the Singapore Ministerial Declaration (December 1996) acknowledged the importance of international labor standards and identified the International Labor Organization (ILO) as the competent body to establish and monitor labor standards. On balance, the WTO Ministerial was implicitly reflecting a view that the agitation in favor of labor standards is motivated principally by a desire to protect domestic labor interests rather than a humanitarian concern for workers in global-supply chains. However, following the Singapore Ministerial, the effort to link the establishment of labor standards in the ILO to enforcement within the WTO multilateral framework was not pursued further.

Other than Article XX(e), the only human-rights exception permitted in the WTO is the Waiver Concerning Kimberly Process Certification Scheme for Rough Diamonds, ${ }^{4}$ issued by the WTO General Council in 2003. The Kimberly Process certifies diamonds not originating from countries in which illegal trade in diamonds is funding gross human-rights violations. As noted by Schefer (2005), the waiver allows WTO members participating in the Kimberly Process to prohibit imports of uncertified diamonds, normally a violation of the nondiscrimination

\footnotetext{
${ }^{3}$ It should be noted that what constitutes human rights is broader than the specification of labor rights, which, as noted, cover conditions in the workplace. Our focus in what follows is primarily on issues of labor rights.

${ }^{4}$ Decision of 15 May 2003, WT/L/518 (27 May 2003).
} 
provisions of the WTO Charter. However, while some of the human-rights violations targeted by the Kimberly process concern the treatment of laborers in diamond mines, the role that diamond profits play in human-rights violations that arise during armed conflict is the principle focus of the Waiver.

Advocates for international labor standards ultimately gained access to the process of rules-setting in the WTO indirectly through Article XXIV governing the creation of customs unions and free trade agreements (FTAs) and, more importantly, the 1971 GSP Decision, ${ }^{5}$ permitting special and differential treatment of developing country exports. The GSP waiver permits all WTO members to extend preferential tariff treatment to the exports of developing countries. The principle of special and differential treatment for developing countries was made a permanent feature of GATT 1994 by the adoption of the Enabling Clause of 1979. ${ }^{6,7}$ While the WTO charter establishes some of the terms limiting the use of preferential trade agreements, there are no restrictions on conditionality relating to labor standards and enforcement for countries invoking Article XXIV or the Enabling Clause. ${ }^{8}$

The practice of imposing minimum conditions of work in trade agreements emerged in legislation establishing the 1983 Caribbean Basin Economic Recovery Act (USA), the 1984 renewal of the US GSP, and the 1988 Community Charter of the Fundamental Social Rights for Workers, ultimately adopted by all European Union (EU) members. The U.S. GSP Renewal Act

\footnotetext{
${ }^{5}$ GATT Document, Generalized System of Preferences ('GSP Decision’) (25 June 1971) BSD 18S/24. It is important to note, however, that actions relating to labor standards are not otherwise covered by the WTO dispute settlement procedures.

${ }^{6}$ GATT Document, Differential and More Favorable Treatment, Reciprocity and Fuller Participation of Developing Countries ('Enabling Clause’) (28 November 1979) L/4903 para 2(a).

${ }^{7}$ Hoekman and Özden (2005).

${ }^{8}$ However, as Kimberly Elliott has suggested to us, the disciplines have been difficult to enforce in practice. And there has been one case_-by India_challenging the conditions in the EU's GSP as being discriminatory.
} 
of 1984 specifically sought to protect: (1) the right to freedom of association, (2) the right to organize and bargain collectively, (3) a prohibition on the use of any form of forced or compulsory labor, (4) a minimum age for the employment of children and (5) acceptable conditions of work with respect to minimum wages, hours of work, and occupational safety and health. ${ }^{9}$ The Act also provided for enforcement. The established mechanism identified a threshold for petition review by the United States Trade Representative (USTR). As noted in Compa and Vogt (2001), domestic workers, trade unions and religious and human-rights activists could file a complaint, present evidence and argue for removal or suspension of benefits based on labor-rights violations. Between 1984 and 2001, 13 countries were suspended from US GSP status, and 17 were placed on temporary extension with continuing review. ${ }^{10}$

Labor standards in the Chile-U.S. (2003) and Singapore-U.S. (2003) FTAs are limited to requiring governments to enforce their own domestic labor law, and a fine may be imposed for noncompliance (see Stern, 2003; Polaski, 2004). ${ }^{11}$ The text of the agreements also includes respect for the ILO’s Declaration on Fundamental Principles and Rights at Work, but failure to comply is excluded from dispute resolution, according to Elliott (2004). Somewhat more expansive terms have been included in the North American Free Trade Agreement (NAFTA) and the U.S. Trade Agreement with Jordan (2001). Under the terms of the Jordan-U.S. FTA, each country has the right to challenge the partner's protection of labor rights. Adjudication is

\footnotetext{
${ }^{9}$ GSP Renewal Act of 1984, Pub. L. No. 98-573, 98 Stat. 3019 (1984).

${ }^{10}$ Suspensions: Romania (1987), Nicaragua (1987), Paraguay (1987), Chile (1987), Burma (1989), Central African Republic (1989), Liberia (1990), Sudan (1991), Syria (1992), Mauritania (1993), Mauritania (1993), Maldives (1995), Pakistan (1996), and Belarus (2000).

${ }^{11}$ Kimberly Elliott has pointed out to us that NAFTA was also based on enforce-your-own-laws standards, although the institutional mechanism for complaints was more elaborate.
} 
undertaken by a neutral international dispute resolution panel. Penalties for an adverse finding include imposition of tariffs (see Polaski, 2004).

More expansive terms have been imposed through conditions in the European Union (EU) GSP. The EU GSP requires the ratification and implementation of the ILO's Fundamental Rights at Work: (1) freedom of association and collective bargaining, (2) elimination of forced labor, (3) eradication of child labor, and (4) abolition of discrimination. GSP beneficiaries are subject to supervision through the standard enforcement mechanisms of the ILO memberstate reports and tripartite reports of noncompliance (see Cavaglia, 2010).

A mechanism for linking ILO-established labor standards, monitoring by the ILO and enforcement through the threat of lost trade concessions emerged fully operational in the 1999 U.S.-Cambodia Bilateral Textile Trade Agreement. ${ }^{12}$ The ILO Better Factories Cambodia ${ }^{13}$ (BFC) program, to be discussed below, engages in monitoring and reporting on working conditions in Cambodian garment factories according to ILO Core Labor Standards and Cambodian labor law. Under this trade agreement, the United States provided Cambodia access to US markets by giving expanded apparel and textile quotas conditional on improved working conditions in the garment sector (see Polaski, 2009).

The ILO and the International Finance Corporation (IFC) jointly agreed to extend Better Factories Cambodia into a global program in 2006. The ILO/IFC Better Work Program, inaugurated in 2008, establishes labor standards in eight areas: child labor, forced labor, freedom of association and collective bargaining, discrimination, contracts, compensation, occupational safety and health, and work hours.

\footnotetext{
${ }^{12}$ However, Kimberly Elliott has suggested to us that Polaski (2009) stresses that what made this agreement unique was that it used positive incentives - the potential for increased access - rather than threat of loss to encourage reform.

${ }^{13}$ For more information, see http://www.betterfactories.org .
} 
Better Work country programs are currently operational in Cambodia, Vietnam, Jordan, Lesotho, Haiti, Nicaragua, and Indonesia, though each country program varies with national labor law and applicable trade agreements. For Vietnamese factories, participation in Better Work is entirely voluntary unless required by a principal buyer. For Jordan, participation by apparel factories was initially voluntary. However, as in Cambodia, the Jordanian government is promulgating rules requiring apparel factories producing for export to the United States to enroll in Better Work Jordan. The HOPE II legislation requires Haitian factories to enroll in Better Work Haiti. In addition, each factory in Haiti must reach a minimum level of compliance in order to receive preferential access to the U.S. apparel market. ${ }^{14}$

Thus, Article XXIV and the Enabling Clause have allowed for the establishment of labor standards within the WTO. As anticipated by the 1996 Singapore Ministerial Declaration, the ILO has been tasked with promulgating and monitoring compliance with international labor standards. However, contrary to Ministerial dictates and according to Kimberly Elliott, actual enforcement of labor standards has been rare rather than routine, in terms of the prospective loss of preferential tariff concessions and market access.

Critics of labor-standards provisions in trade agreements typically argue that domestic protectionism is masquerading as humanitarian concern for workers in developing countries. While it is likely true that domestic labor interests are one of the driving forces behind international labor standards, it remains the case that there are market failures that are aggravated by integration of global markets. These market failures may have severe adverse consequences for workers in developing countries, and they can be remedied through the imposition of labor standards. Thus, in Section II, we survey the labor and human-rights issues that emerge in a

\footnotetext{
${ }^{14}$ David Kucera has suggested to us that an important part of the BFC and BW programs is that they offer various forms of training, such as human-resource management and shop-floor efficiency. While it is not clear how effective these programs have been, they can be viewed as potentially offsetting costs of stronger compliance.
} 
globalizing world economy, the market failures that produce labor and human-rights violations, and the role of labor standards in mitigating the most grievous of consequences. Section III is devoted to a presentation of the evidence on the impact that labor standards in international trade agreements may have on trade, firm behavior, and workers. Conclusions follow.

\section{Human Dignity in an Integrated Global Economy}

The case for or against including labor standards in trade agreements depends, in part, on the market process that each standard is intended to constrain. The theoretical case in favor of linking labor protections and international trade is advanced by Bagwell and Staiger (2001). They note that tariffs and labor protections are policy substitutes. A government that commits to tariff reductions during a round of international-trade negotiations can ex post achieve its protectionist objectives by reducing costly protections for workers in the import-competing sector. As a consequence, negotiating over tariffs alone will give rise to inefficiently weak domestic protection of labor and inefficiently low openness to international trade.

However, despite the strategic link between domestic labor protections and trade policy, Bagwell and Staiger's analysis does not suggest that coordination of trade and labor protections should take the form of labor standards in the WTO. Rather, WTO members who do not realize the expected market access from a round of trade negotiations as a consequence of ex post changes in the labor law of its trade partner can lodge a nonviolation complaint under GATT Article XXVIII. This allows the plaintiff to retract tariff concessions made in a previous round if promised market access is not realized due to subsequent actions by the partner's government. A complaint can be lodged even if the action of the protecting government is legal within the rules of the WTO. The threat of retaliation, then, for changes in labor protections that limit expected market access will eliminate the strategic benefit of the domestic-policy change. Thus, the 
efficient configuration of labor protections and tariffs can be achieved without incorporating labor standards directly into trade negotiations.

The analysis of Bagwell and Staiger focuses on the strategic link between labor standards and trade. Srinivasan (1998) considers humanitarian motivations for international labor standards. He first argues that the heterogeneity of cross-country standards is reasonably the consequence of variations in tastes and income. Free trade is the optimal policy in the face of such working-conditions heterogeneity. To the extent that standards heterogeneity gives rise to human-rights violations, Srinivasan, citing Rawls (1993), argues that the most efficient mechanism for addressing human-rights concerns in trade partners is simply to allow for free international migration of labor. A second mechanism for internalizing the external effect of poor conditions of work on those with a concern for human rights is to provide for income transfers, reflecting the willingness to pay for humanitarian conditions of work.

Despite the theoretical elegance of the Bagwell-Staiger and Srinivasan analyses, little of their proposed mechanisms have been adopted to address concerns with working conditions in global-supply chains. The only exception concerns the use of transfers to compensate developing countries for the adoption of labor protections.

The first and most direct transfer emerges as a consequence of the adoption of labor standards in preferential trade arrangements (PTAs). To the extent that the developing countries in PTAs are small relative to their preferential trading partners, the agreements generate a transfer from the developed to the developing country. Small developing countries are able to sell to their larger partners at the world price plus the tariff applying to exports of non-members. The transfer of tariff revenue to the developing-country trade partner can be thought of as compensation for their agreement to adopt certain labor standards. 
However, it should be noted that transfers generated through PTAs are not first best. ${ }^{15}$ That is, PTAs introduce distortions between member and nonmember trade partners, giving rise to a loss of efficiency relative to a multilateral agreement.

A second strategy has been to employ market-based mechanisms to improve conditions of work in developing countries (see Elliott and Freeman, 2003; O’Rourke, 2003). Consumerproduct labels detailing conditions of work can, in principle, allow consumers with a disutility for consuming goods produced under inhumane conditions to increase utility by choosing goods produced under humane conditions. However, if the consumer demand for humane conditions of work is small relative to the overall market, it is possible for the market to direct goods already produced under humane conditions of work to those consumers concerned with working conditions. While consumers may be better off, there is no consequence for workers either in terms of wages or conditions of work (see Brown, 2006).

Furthermore, market-based mechanisms cannot remedy the more likely case in which the humanitarian concern for the well-being of workers is a public good. A consumer-product label potentially allows a human-rights-sensitive consumer to choose goods produced under humane conditions of work. However, the external effect generated from the consumption by others onto the human-rights-sensitive consumer is not internalized by a product label.

Given the political and practical challenges of a right to international migration, tariff retaliation and a system of income transfers for addressing human-rights violations, the linking of labor standards and trade has emerged as the preferred option in this constrained policy environment. Linking market access and labor standards has at least two theoretical

\footnotetext{
${ }^{15}$ It may also be the case that compensation is not necessarily to those harmed.
} 
justifications. Spagnolo (2001) argues that linkage should occur when trade and labor standards are viewed as policy substitutes. Policy objectives are substitutes when failure to achieve an agreement on one issue increases the value of achieving agreement on the other. In this setting, linking negotiations increases the cost of a negotiating failure, providing greater incentive for negotiating parties to reach agreement.

Linkage may also be desirable if negotiating parties are having more difficulty in establishing an enforcement mechanism for labor standards than for trade standards. Using trade punishments to enforce trade and labor agreements transfers some enforcement power from trade to labor. The consequence, of course, as Limão (2005) has noted, is that a linked agreement will have stricter labor standards but less trade liberalization than two unlinked agreements.

\section{Globalization, Labor and Human-Rights Violations, and the Remedy for Market Inefficiency}

Below we detail seven labor-standards categories, in each case exploring the link between globalization and labor and human-rights violations, as well as the market inefficiency or inequity that a standard would remedy.

Forced Labor and Human Trafficking. ${ }^{16}$ Human trafficking typically involves kidnapping, inducing workers to migrate based on false pretenses, or physically preventing workers from abrogating a labor contract. The most egregious cases involve trafficking of women or children into sex slavery. Less horrific but still a violation of labor and human rights are the cases of migrant workers who do not control their travel documents, working papers, or

\footnotetext{
${ }^{16}$ While these are the forms most related to globalization; traditional debt bondage is still a problem in some places and may have little/no link to globalization, as Kimberly Elliott has pointed out to us.
} 
residency permits. Such restrictions on the freedom of movement are a violation of the corelabor standard prohibiting forced labor.

Clearly, violations related to forced labor arise due to a governmental failure to protect each individual's property-rights claim to her or his own body. Domestic legal structures that permit forced labor generate a transfer from the individual to the trafficker and incidentally exert downward pressure on wages and employment opportunities for workers with fully protected property rights. Following Srinivasan, ${ }^{17}$ human-rights activists may attempt to transfer wealth to a government that is failing to protect property rights or buy the right to the worker from the trafficker. However, in both cases, the use of a positive transfer provides a perverse incentive to increase trafficking in order to elicit a larger payment from the human- rights activist. A negative penalty attached to the failure to prohibit trafficked/forced labor, such as a refusal to trade in goods produced with trafficked/forced labor, provides a well-targeted tax on the humanrights violation (see Srinivasan,1998). ${ }^{18}$

Child Labor. In contrast, a standard prohibiting the employment of children, while profoundly morally compelling, is challenging to justify from an efficiency or equity perspective. Theory and evidence on the causes, consequences and effective policies targeting child labor have been exhaustively studied and surveyed (see Basu, 1999; Brown et al., 2003; Edmonds, 2008).

\footnotetext{
${ }^{18}$ David Kucera has pointed out to us and as noted above, debt bondage may be the most prevalent form of forced labor. Since poverty increases vulnerability to debt bondage, it may be similar to some forms of child labor in this regard. A useful volume dealing with debt bondage is Andrees and Belser (2009). It may also be noted that not all trafficked labor will necessarily be forced. For example, as Kimberly Ellioiot has suggested to us as an example, Mexican migrants who use coyotes to cross the U.S. border may then look for work on their own, so that this may not strictly be a form of trafficking.
} 
The level of child labor may be inefficiently high as a consequence of several market failures. From an efficiency perspective, the decision between work and school depends on the wage that the child could earn in current employment relative to the present discounted value of the future earnings as an educated adult. As Baland and Robinson (2000) note, however, binding credit constraints limit the ability of a family to make efficient education investments. Multiple remedies exist, including providing credit, conditional cash transfers that replace earnings for children attending school, improving school quality and availability, and relieving poverty. In fact, cross-country empirical evidence presented by Edmonds and Pavcnik (2006) provides strong support for the hypothesis that poverty is the decisive determinant of the work-school choice. Further Edmonds and Pavcnik (2005a; 2005b) find that income growth associated with trade liberalization is correlated with a decline in child labor and increased schooling.

Labor standards that prohibit the employment of children without addressing the root causes of poverty and credit constraints pose a risk of unintended consequences. Empirical inquiry on the impact of prohibitions against child labor and mandatory education provide little evidence that a regulatory approach is likely to have a significant positive effect on working children. Lleras-Muney (2002) finds evidence that U.S. laws regulating the minimum age for obtaining a work permit during the early part of the $20^{\text {th }}$ century increased the school completion rate for white males. However, Goldin and Katz (2003) argue that mandatory education and minimum age-of-work laws accounted for no more than five percent of the increase in school enrollment during the first four decades of the $20^{\text {th }}$ century.

The lone exception to the above analysis concerns the case in which a child is sold into bonded servitude and compensated only with subsistence housing, food and water. In this case, 
the guardian selling the bond has extracted all of the value of the child's labor for his own purposes. Such contracts violate prohibitions against forced labor and exploitative child labor.

Discrimination and Sexual Harassment. Similarly, an efficiency-based justification for linking market access and nondiscrimination is difficult to establish. No demographic group has been more positively affected by globalized markets than women. The pro-competitive effect of international trade has been one factor in narrowing the gender gap in industrialized countries. As Black and Brainard (2004) note, globalizing firms are highly motivated to minimize the cost of production, an objective incompatible with a taste for discrimination on the part of managers and supervisors. Further, Busse and Spielmann (2006) find that gender-wage inequality is a significant factor in explaining the comparative advantage of developing countries. ${ }^{19}$ Globalsupply chains appear to seek out markets in which the alternative employment opportunities for women are limited. To the extent that discrimination is observed in sectors such as the apparel industry, it is against men and pregnant women, according to Warren and Robertson (2010).

It is noted in World Bank (2004) that the poorest women in the world have discovered new employment opportunities in apparel, footwear, jewelry, electronics, and call centers, etc. For example, according to Paul-Muzumdar and Begum (2000), in Bangladesh, two-thirds of the 2 million newly created jobs in the apparel industry are held by women. For many of these women, employment opportunities created in global-supply chains may be the first formal work experience other than prostitution. Another example is that 85 percent of women newly employed in the Madagascar apparel industry had never previously received compensation in the form of cash, as compared to 15 percent for men, according to Nicita and Razzaz (2003).

\footnotetext{
${ }^{19}$ David Kucera has suggested to us that different forms of gender equality could have opposite effects. Busse and Spielmann, for instance, point to the positive association with gender-wage inequality and the negative association with educational attainment and labor-force activity rates. In this connection, see especially Van Staveren, Elson, Grown, and Cağatay (2007).
} 
Earning money wages raises the status of women, having long-run consequences particularly for the educational attainment of girls.

Yet, the impact of globalization is not monotonically positive. As women transition from traditional nonmarket work to market work, there is evidence that men in traditional societies continue to process the market activity of women through a traditional lens. Prior to the arrival of a garment factory in a traditional society, prostitution is often the only paid occupation in which women have previously participated. As a consequence, as noted by Khosla (2009), women employed in a newly opened apparel factory are seen as equivalent to prostitutes and, thus, are often subjected to sexual harassment. Women are also disproportionately negatively affected when globalized industries shift to a lower-wage market (see Levinsohn, 1999).

Labor standards prohibiting sexual harassment could potentially speed the transition to a modern perception of paid female employment. In the interim, monitoring sexual harassment in a factory setting will increase the willingness of community elders to permit the market employment of women.

Freedom of Association and Collective Bargaining. The right to join a union is the standard that appears to evoke the most intensely negative response among labor-standards critics. Unions can be anti-competitive and corrupt, and they can limit the flexibility of a firm to adapt to a changing market environment. The empirical evidence, though, paints a less toxic picture of the effect of unions on economic performance. Aidt and Tzannatos (2002) survey research on the impact of the rights to freedom of association and collective bargaining on economic growth, and they find no systematic relationship. The only significant effect appears to be that high union density reduces wage inequality. 
Elliott (2004) argues that integrated labor markets improve the cost-benefit ratio of union activity. First, as noted in Freeman and Medoff (1984), the unions subject to the competitive pressure of international trade enhance the voice face while constraining the monopoly face of unions. Unions provide a voice to workers in developing countries for several reasons: (1) Migrant labor with restricted movement may lack a meaningful market mechanism for disciplining employers. As will be discussed below, migrant workers are typically tied to a single employer, limiting their ability to move to an employer that pays a higher wage and/or offers better conditions of work. (2) Conflict over reasonable hours of work and the tradeoff between wages and working conditions can only be resolved through negotiation between workers and firms. (3) Low-literacy workers with limited market experience may lack the communication and bargaining skills necessary to guarantee that they are paid as promised, are not subject to excessive hours of work, or exposed to extremely hazardous working conditions.

Compensation, Contracts, and Hours. Critics of international labor-standards harmonization commonly focus intense attention on "cash” or "outcome” standards. Such standards involve the terms of employment particularly related to hours and wages. The outcome of bargaining between workers and firms must by necessity reflect underlying technology and constraints imposed by goods and factors markets. Heterogeneity in wages and working conditions across industries and countries is an inevitable reflection of cross-country variations in productivity and income.

However, labor standards, as implemented by the ILO in connection with trade agreements, do not impose uniform wages or hours on all markets or industries. ${ }^{20}$ Rather, firms

\footnotetext{
${ }^{20}$ In this connection, see Brown and Stern (2008), who argue that efforts to improve labor standards have to be tailored to the economic and social circumstances prevailing in a country at a specific time. Legalistic means to prod governments into revising their domestic laws or enforcing them will therefore be unsuccessful unless economic incentives can be changed to erode prevailing social norms and ease the way for the acceptance of new norms that
} 
in each country are required only to adhere to national law. Nevertheless, the question still remains: what market failure is an "outcomes” standard designed to address?

Labor-management practices in developing countries often follow the traditional human resource (HR) model, including extremely fine division of labor, piece-rate pay, close monitoring of work effort, one-directional communication, etc. (see Ichniowski, Shaw, and Prennushi,1997). Arguably, technology is determining the HR choice since work effort in simple production processes is easily observable and, therefore, perfectly contractible, as noted in Lazaer and Oyer (2007). However, the empirical evidence on the use of high-powered incentives such as piece rate pay is mixed. Bandiera et al. (2007) find that piece-rate pay increases productivity in traditional industries relative to hourly pay. However, Hamilton et al. (2003) find that HR innovations including production teams increase productivity and workplace satisfaction relative to use of alienating high-powered individual piece-rate pay.

More seriously, labor-management practices in developing countries commonly fall below even the traditional system. Workplaces employing a sweatshop HR system characterized by nonpayment of wages, extreme hours of work, and physical and sexual abuse, etc., are common, according to the National Labor Committee (2006). Such factory managers pay workers the reservation wage and then employ nonpecuniary motivational techniques such as verbal and physical abuse to elicit work effort. These sweatshop-labor-management practices are unrelated to the nature of technology, stemming rather from an ability to exploit low-literacy, docile female workers with limited market experience.

will meet with public approval and be consonant with the distribution of political power. Moral suasion from both domestic and external sources may work more slowly than more legalistic means but is preferred because it contributes to altering the social norms that underlie and will reinforce the acceptance and effectiveness of labor standards. 
Falk et al. (2006) and Lazear and Oyer (2007) note that HR innovations that improve efficiency may also enhance a sense of worker agency and perceptions of fairness, increasing labor's relative bargaining power and reducing capital's share of any economic rents earned by the firm. The tension between economic efficiency and firm profits is highlighted by Freeman and Kleiner (2005). In one factory-based intervention, Nike worked with a Chinese footwear factory to experiment with the use of pay incentives for line workers. But despite the fact that pay incentives were found to increase productivity, the factory reverted to pre-experiment pay practices at the end of the study.

Labor standards designed to require employers to pay workers as promised and prohibit verbal and physical abuse impose a binding constraint on the range of HR systems available to a factory. Weil (2005) notes that efficiency-enhancing HR innovations in the presence of labormarket imperfections characteristic of developing countries may be profit-maximizing only within the confines of a set of clearly articulated and enforced binding constraints such as laws, corporate codes, or international labor standards. Employers no longer able to employ an exploitative sweatshop model will be required to adopt innovations that include the use of pay incentives to elicit work effort and respectful communication and problem-solving. Such labor standards will not constrain the management options of firms employing a traditional (or more complex) HR system, according to Brown, Dehejia, and Robertson (2010).

Occupational Safety and Health. Hazardous conditions of work range from the exposure to lint dust in an apparel factory to exposure to toxic chemicals in the recycling of electronic waste. Workplace hazards can be efficiently managed through the provision of protective equipment and/or the payment of a compensating differential for employment involving health risks. A market failure may arise in the presence of an information asymmetry 
between the worker and the employer. The cost of acquiring information and monitoring employer compliance with agreements to manage workplace hazards may be prohibitively high for a low-literacy worker lacking employment experience.

At a minimum, efficiency would require the employer to disclose known health risks associated with a particular task. However, a worker's ex ante evaluation of the tradeoff between monetary compensation and occupational health may differ from the ex post evaluation once the worker has had an opportunity to realize the negative health consequences associated with a particular task. In such a case, a labor standard prohibiting certain types of work contracts may produce an efficiency gain.

Poverty. The textbook Heckscher-Ohlin model of international trade leads us to expect that international trade will increase economic welfare and narrow the distribution of income in unskilled labor-abundant countries. Trade creates the opportunity to specialize in the production of goods in which a country has a comparative advantage, thereby increasing equilibrium income. To the extent that relative factor abundance determines comparative advantage, international trade should raise demand for the abundant factor and increase its return. For lowincome countries, the abundant factor (unskilled labor) is also the poor factor. Thus, international trade should raise the income of the poorest workers in the world both absolutely and relative to other factors of production, as noted in Krueger (1983) and Bhagwati and Srinivasan (2002). Indeed, Warcziarg and Welch (2008) find compelling cross-country evidence that trade liberalization increases economic growth.

Evidence of the positive impact of globalization on poverty alleviation is nowhere more evident than in the apparel industry. The positive impact emerges in the form of a wage premium in apparel employment, expanded formal employment opportunities for women, better 
conditions of work, less hazardous employment, job security, and higher educational attainment particularly for girls. Robertson et al. (2009), analyzing household survey data in Cambodia, El Salvador, Honduras and Indonesia, find that the apparel industry pays a wage premium even after controlling for worker characteristics. For example, workers in the Cambodian apparel industry earn 80 percent more than the average worker with similar skills, experience, and gender. The wage premia in other developing countries are smaller but still quite significant, such as in El Salvador (18.8\% in 2000), Honduras (21.5\% in 2004), and Indonesia (7.4\% in 2004). Robertson et al. also find that the apparel industry is characterized by lower accident rates and better employment and social security. Work hours are longer than in other occupations, though it is unclear whether this is a worker or employer choice.

The end of the Multi-Fibre Arrangement (MFA) provides additional evidence of the positive and negative consequences of globalization. Nicita and Razzaz (2003) simulate a fiveyear expansion of the textile industry in Madagascar and find that purchasing power for a household with a member employed in the textile industry could potentially rise by 24 percent. Yet, following the end of the MFA, workers in the Zone Franche in Madagascar suffered a 20 percent decline in pay relative to workers outside the zone, according to Cling, Razafindrakoto, and Roubaud (2009).

Higher wages and expanded employment opportunity for women in the apparel industry have had deep consequences for the social outcomes for women and girls. Khosla (2009), surveying the literature on the impact of the ready-made garment industry in Bangladesh, finds evidence of greater economic independence, respect, social standing, and voice for women. More strikingly, Bajaj ${ }^{21}$ reports on research by Mobarak, ${ }^{22}$ which finds that the school-

\footnotetext{
${ }^{21}$ http://economix.blogs.nytimes.com/2010/07/21/garment-factories-changing-womens-roles-in-poor-countries/
} 
enrollment rate of Bangladeshi girls aged 5 to 18 is approximately seven percentage points higher in villages with a garment factory as compared to other villages. Similarly, Oster and Millett (2010) find that the introduction of a call center in India raises the number of children in school in the local community by 5.7 percent. Yet, rightly or wrongly, the WTO has acquired a corporatist reputation in which the rules appear to greatly favor the interests of producers. As Maskus (1997) notes, the 'social clause' advocated during the Uruguay Round was intended to provide the same type of protection for labor that the Trade Related Intellectual Property Rights Agreement (TRIPS) provides to the owners of intellectual property. Under the prevailing set of rules in the WTO, globalization alters the power relationship between capital and labor by protecting: (1) market access for exports, (2) physical and intellectual property rights, and (3) the international mobility of capital. Labor, by contrast, is not guaranteed any protections within the WTO and is subject to considerable restrictions on international migration. Economic integration under the terms of the WTO charter could, in principle, lower labor's cost share as capital moves or threatens to move to markets with the lowest labor costs and weakest restrictions on the employment of labor. Labor standards are proposed first and foremost to lower the probability that labor loses absolutely as the consequence of globalization and secondarily to preserve labor's current share of income.

Indeed, despite the overall positive picture in evidence at the macro-level, there remains considerable evidence that trade lowers the relative wages of unskilled workers particularly in developing countries, and there are notable episodes in which liberalization has increased poverty. Though there are many potential explanations, Harrison (2007) notes that unskilled

\footnotetext{
${ }^{22}$ http://www.som.yale.edu/faculty/am833/
} 
labor in developing countries is less mobile than other factors and is, therefore, unable to take advantage of new employment opportunities created by international trade.

More importantly, the poorest workers in the world with limited literacy, savings, and market experience are vulnerable to exploitation. Harrison and Scorse (2010), notably, find that prior to the anti-sweatshop campaign undertaken in Indonesia during the mid-1990s, foreignowned and export-oriented firms had poorer compliance with minimum-wage laws than comparable domestic firms supplying the domestic market. Pressure by international buyers to raise wages in the textile, footwear, and apparel industries improved minimum-wage compliance and lowered profits without lowering employment. These findings are consistent with the hypothesis that successful exporters are more effective in monopsonistic wage-setting behavior than other firms.

Jordan provides a second example in which firms producing for export are seeking regulatory settings in which monopsonistic employment practices are feasible. The Qualified Industrial Zone (QIZ) Agreement, signed by the United States and Jordan in 1999, was developed as part of the U.S.-facilitated Palestinian-Israeli peace process. Tariff concessions were provided to Israeli exports provided that they had 11.7 percent value-added in Jordan and eight percent from Israel. ${ }^{23}$ The expectation was that the QIZ agreement would provide economic incentives for Israeli capital to work with Palestinian labor, thereby creating economic interdependence between these two factions. ${ }^{24}$

The weakness in the QIZ Agreement, however, is that there was no requirement that eligible factories hire Palestinian workers in order to obtain preferential treatment. Nor was

\footnotetext{
${ }^{23}$ In addition, the collective value-added by the United States, Jordan, Israel, and the West Bank and Gaza must be 35 percent.

${ }^{24}$ However, Kimberly Elliott notes that the QIZ factories are in Jordan, and the exports are from Jordan. Since Israeli has its own FTA, it would not need the QIZ. It may be that the QIZ was negotiated as a reward for Jordan negotiating a peace deal with Israel; Egypt has a similar agreement.
} 
there any requirement that the capital be Israeli owned. While the Agreement had some initial success creating 17,654 jobs for Jordanians by 2004, since that time the Jordanian share of apparel employment has steadily declined. ${ }^{25}$ This is the case, even though the unemployment rate for Jordanian women is over 25 percent.

Factory owners prefer to import migrants from Bangladesh, India, Sri Lanka, and China. The preference for migrant labor stems in part from an asymmetry between the legal treatment of Jordanians and migrants in laws regulating work, residency permits, and rights to freedom of association and collective bargaining. Jordanian workers are permitted to join a union and are free to move from one employer to another. However, a migrant receives a work permit for employment only at a sponsoring firm. A migrant worker can change jobs, though only with the permission of the sponsoring employer. As a consequence, migrant labor is not free to move to a factory with higher pay and/or more desirable working conditions, and migrants were apparently excluded from Jordanian labor laws. Thus, the competitive mechanism that normally protects workers from monopsonistic exploitation is disabled.

More generally, according to Warren and Robertson (2010), ILO monitoring in Cambodia, Vietnam, Jordan, and Haiti has found frequent compensation-related violations including: (1) failure to comply with minimum wage law, (2) failure to provide information about the wage calculation, (3) excess deductions, (4) excessive payment in-kind, (5) failure to pay wages as promised, (6) failure to pay on time, and (7) improper calculation of overtime compensation. Violations related to hours of work are also common, including forced overtime, excess overtime, and failure to provide weekly rest.

\footnotetext{
${ }^{25}$ Kimberly Elliott notes that part of Jordan's response to the sweatshop scandal was to formally adopt a policy of encouraging Jordanian employment in the garment sector, but the effect of the policy remains to be determined.
} 
A set of labor standards that requires employers to clarify payment calculations and that monitors compliance with basic pay requirements - such as paying wages as promised and setting wages consistent with the statutory minimum wage - could inhibit the ability of employers to engage in monopsonistic wage-setting behavior and improve the overall competitiveness of the labor market. Such standards would allow the market to set the wage level consistent with labor productivity, while providing workers the information required in order for them to choose the employer with the constrained utility-maximizing pay and benefits package.

\section{Empirical Evidence on the Impact of Labor Standards on International Trade and Investment: Is There a Race to the Bottom?}

The implications of labor standards can be most readily seen from their implementation in practice. Below, we provide detailed experience from the U.S. Generalized System of Preferences (GSP) and Better Factories Cambodia, and we also review more broadly the impact of labor standards on international trade and investment.

\section{The Experience of U.S. GSP and Better Factories Cambodia}

The early use of the violations-petitioning process provided for by the US GSP highlights the connection between labor rights generally and freedom of association specifically with emergent democracy. The first two successful petitions were brought against Chile (1986) and Guatemala (1988). Both cases involve the downfall of violently repressive military regimes targeting labor organizers.

The petition filed in 1986 by the AFL-CIO against Chile followed more than a decade of violent repression of union rights, the murder in 1982 of Tucapel Jimenez (a public-employee workers-union member) and the 1985 murder of three teachers' union leaders. The Chilean 
government argued against suspension of GSP status, claiming that they were taking "positive steps,” halting the killing, jailing, and harassment of union leaders. However, violations continued, leading to Chile's suspension from the U.S. GSP in February $1988 .{ }^{26}$ Compa and Vogt (2001) argue that loss of preferential treatment of Chile's exports to the U.S. market undermined business support of the government and was a factor in the transition to democracy.

The petition against Guatemala was filed with the United States Trade Representative (USTR) in 1988. The petition provided evidence of assassination, arrests, and torture of tradeunion activists and repressive provisions of the Guatemalan Labor Code. Yet despite the compelling evidence of labor-rights violations, the USTR rejected all petitions. USTR staff argued that the human-rights violations were not a direct reprisal for their trade-union work. ${ }^{27}$ Yet, faced with mounting evidence and repeated petitions, the US Trade Policy Staff Committee (TSPSC) accepted a petition for review in 1992.

Shortly thereafter, Guatemala’s GSP status became a factor in restoring democratic rule. In mid-May 1993, Guatemala’s president Jorge Sarrano dissolved the Parliament and the Supreme Court. By mid-June 1993, under threatened loss of GSP status, human-rights advocate Ramiro Deleon Carpio was installed as the President, and Serrano was exiled. The loss of support from the business community linked to Guatemala’s GSP status was a critical factor.

By contrast, petitions involving Malaysia, Indonesia, and Pakistan were less successful. Compa and Vogt (2001) argue that business opposition marshaled by the U.S.-ASEAN Council for Business and Technology successfully blocked review of Indonesia by the USTR. ${ }^{28}$ The

\footnotetext{
${ }^{26}$ Amending the Generalized System of Preferences, 52 FED. REG. 49, 129 (Dec. 30, 1987).

${ }^{27}$ USTR, GSP Subcommittee of the Trade Policy Staff Committee, Workers Rights Review Summary: Petitions Not Accepted for Review (Guatemala 1988, 1989, 1990 and 1991).

${ }^{28}$ The U.S. ASEAN Council includes Mobil, Texaco, Chevron, American Express, General Electric, General Motors, Nynex, Caterpillar, etc.
} 
Clinton Administration did suspend GSP treatment of Pakistani exports of sporting goods, surgical instruments, and hand-woven rugs in 1996 over the concern with child labor. However, Pakistan's pivotal role in the war in Afghanistan became an over-riding concern, and GSP treatment was reinstated by the Bush Administration.

Despite the failure of the Clinton Administration to deploy the loss of GSP preferences against Indonesia, Harrison and Scorse (2010) document a significant impact of the attendant anti-sweatshop campaign on minimum-wage-law compliance, as discussed above. By 1997, exports from factories in districts from which Nike sourced were more compliant than domestic firms.

A significant aspect of the US GSP stems directly from the binary link between working conditions and preferential treatment. A finding of noncompliance and a loss of GSP status had a dramatic impact on government stability, local businesses, American business interests and the implementation of U.S. foreign policy during the 1980s and 1990s.

Intentionally or not, evolution of the labor standards in the international trading system addressed the consequences of such high-stakes implementation. A revised labor-standards framework employed in agreements between the United States and Mexico, Chile, and Jordan dramatically lowered the level of tension over working conditions in developing-country trade partners. These agreements typically require each government to enforce their own labor law and failure to do so is not the subject of dispute resolution.

Perhaps more importantly, removal of monitoring to the ILO ratcheted down the power of the incentives embedded in the US GSP scheme. The ILO employs a consultative tripartite approach rather than confrontation. Factories are inspected against the set of core standards and national labor law. Factories are offered an opportunity to respond and noncompliance is 
publically disclosed. The ILO then engages factories in consultation and training aimed at remedying noncompliance. However, for most factories (excluding those in Haiti), the main consequence of noncompliance is the impact that reports have on current and prospective business relationships and the public embarrassment of disclosure of noncompliance.

Furthermore, beyond the core labor standards, the ILO relies on national labor law to establish the baseline against which factories are monitored. ${ }^{29}$ The ILO issues a report determining whether a factory is in compliance with the local minimum-wage law and whether workers are paid as promised, thus removing the common criticism of outcome standards which reflect industrialized country expectations of pecuniary and nonpecuniary compensation.

The ILO monitors are also less vulnerable than the USTR to the pressures that emanate from geopolitical concerns and business interests. Regulatory independence is obviously a consequence of the fact that ILO monitors are not employees of any government.

Finally, considerable attention has also been paid to establishing and demonstrating a business case for workplace organization that is also compliant. Monitoring imposes a binding constraint on the human-resource-management system selected by a factory manager. Evidence discussed above supports the case that the exploitative model, an initial labor-management strategy typically chosen by factory managers, is not the most efficient and may not be the most profitable.

Evidence from the experience of Better Factories Cambodia (BFC) illustrates the impact of the softer enforcement approach employed by the ILO. The U.S.-Cambodia Textile

\footnotetext{
${ }^{29}$ David Kucera has pointed out to us that that the ILO does in fact try to play a more active role in guiding local labor law. On some non-core standards, it advocates putting processes into place, but on others, such as overtime, it has very specific guidelines. Indeed the first ILO convention specifies a maximum of 48 hours, and many other conventions and recommendations are highly detailed regarding what should and should not be acceptable, such as those on occupational safety and health. This suggests that it might be useful to get the views of ILO legal staff who deal with standards and with conditions of work and employment in order to determine what the ILO actually does in individual countries.
} 
Agreement provided for unequivocal linkage between labor-rights enforcement and market access. As Polaski (2004) notes, following steady improvement in labor-law compliance, Cambodia's apparel and textile quota allocation was increased by 12 percent in each of 2002 and 2003 and by 14 percent in 2004 .

Empirical analysis of BFC is supportive of the positive impact on Cambodia. First, BFC monitoring and reporting appears to have given Cambodia a reputation for acceptable conditions of work among large reputation-sensitive international buyers. Polaski (2004) reports that Cambodian exports of quota-constrained apparel expanded by 44.8 percent between 1999 and 2002. By comparison, non-quota constrained apparel exports expanded by 302 percent. While not definitive, this evidence is consistent with the hypothesis that international buyers were attracted by Cambodia's demonstrated reputation for protecting workers rights. According to Polaski (2009), the expansion in exports is mirrored in new job opportunities for Cambodian workers. Apparel employment in Cambodia expanded from 80,000 in 1998 to 350,000 in 2008. The overwhelming majority of these workers are young women aged 18 to 25 who have migrated from impoverished rural households. These workers received \$US 50 per month which is 25 percent higher than the average household income in rural Cambodia.

Polaski (2009) notes that the most common compliance violations uncovered by the ILO concerned: (1) incorrect payment of wages, (2) excess hours of work and forced overtime, (3) occupational safety and health and (4) the right to form a union. Warren and Robertson (2010), analyzing compliance data between 2001 and 2008, find improved average compliance rates across all compliance dimensions.

Further analysis of the BFC compliance data is indicative of either an efficiency wage, monopsonistic exploitation and/or a business case for improved conditions of work. Similar to 
findings by Harrison and Scorse (2010), Warren and Robertson (2010) find no evidence of a trade-off between pecuniary and non-pecuniary forms of compensation. That is, compliance improved across all dimensions even as employment expanded and the unit value of apparel fell after the end of the MFA. These two findings are consistent with a business case for compliance.

Brown, Dehejia, and Robertson (2010) employ two natural experiments to identify the impact of compliance on factory performance. First, prior to November 2006, points of noncompliance were publically disclosed. From November 2006 forward, BFC reported summary compliance statistics only. Subsequently, the financial crisis of 2008 provided an exogenous shock. Prior compliance behavior was used to predict the probability of survival.

Several findings are consistent with a business case for compliance:

(1) The threat of factory-level public disclosure of noncompliance deterred retrogression in compliance. This effect was stronger for factories supplying a reputation-sensitive buyer than for other factories. However, all factories were deterred from retrogression by public disclosure. These findings are consistent with the hypothesis that public disclosure helped Cambodian apparel factories coordinate away from a prisoner's dilemma in noncompliance. Following the end of the public-disclosure period, the rate of improved compliance slowed and retrogression occurred in factories lacking a reputation-sensitive buyer. However, compliance did not return to the baseline even for factories lacking any incentive to remain compliant.

(2) Factories that were more likely to comply than a statistical model predicted were also more likely to survive the financial crisis of 2008 than other firms. That is, idiosyncratic compliers are more resilient than other factories. 
(3) Further evidence of the inefficiency of sweatshop conditions was found by analyzing the correlation between compliance on wages and the probability of closure during the financial crisis. Factories that pay wages as promised, control sexual harassment, and find peaceful mechanisms for management disagreement were more likely to survive the financial crisis. By comparison, factories engaged in ostensibly more sophisticated human-resource-management practices were not more likely to survive.

\section{Other Evidence of the Effects of Labor Standards on Trade and Investment}

Our preceding discussion suggests that there are a number of concerns surrounding governmentally enforced labor protections. In particular, will labor-market forces erode compliance with the core-labor-market protections that comprise: (1) freedom of association and collective bargaining, (2) nondiscrimination in employment, (3) elimination of exploitative child labor and (4) forced labor? A second closely related question is: "Will governments actively reduce statutory protection of core-labor protections in an effort to attract foreign capital and improve international competitiveness? With regard to the foregoing questions, we first consider the evidence on the impact of increased integration with global markets and compliance with core-labor standards. ${ }^{30}$

Black and Brainerd (2004) consider the evidence on nondiscrimination, noting that the intensification of competition that comes about with globalization should pressure firms engaging in gender discrimination to end this sub-optimal practice. They indeed find for U.S. industries between 1976 and 1993 that the residual gender gap narrowed more rapidly in

\footnotetext{
${ }^{30}$ Olney (2011) characterizes labor standards in terms of employment protection based on 17 measures of hiring and firing costs for 30 OECD member countries for the period, 1985-2008, rather than core labor standards per se. Haberli, Jansen, and Monteiro (2011) focus on labor standards in terms of the effects of domestic labor-market regulation in regional trade agreements. Their data set covers information on employment-protection legislation and unemployment benefits for 90 developed and developing countries for the period, 1980 to 2005.
} 
concentrated industries than in competitive industries. Thus, the pressures of international trade appear to erode the ability of firms in concentrated industries to indulge a taste for discrimination.

As our previous discussion made clear, the channels through which trade impacts employment of children are more complex. In their thoroughgoing analysis of Vietnam's integration into the global rice market, as we have noted, Edmonds and Pavcnik (2005a) find that the incidence of child labor depends on each family’s asset holdings. Between 1993 and 1998, Vietnam removed rice-export restrictions, producing a 29 percent increase in the domestic price of rice. From a theoretical perspective, the subsequent rise in the return to land and labor in rice production has an ambiguous impact on working children. On the one hand, the rise in adult wages in rice production increases the opportunity cost of household production. As a consequence, the rise in the wages of rural mothers may lead some families to draw their daughters out of school and into household production. Similarly, the rise in the wages of children working in the rice sector could increase the opportunity cost of child leisure and schooling. Families for which these substitution effects dominate may actually respond to the rise in the price of rice by increasing child labor. On the other hand, rising household income will increase the demand for quality children. Rising household wealth will relax the liquidity constraints that families face when trying to make education investments in their children.

Edmonds and Pavcnik (2005b) find that households with large and medium-sized landholdings reduced the amount of time their children work and increased leisure and schooling. The effect is particularly pronounced for older girls. Thus, the income effect dominated some of the other forces that might have drawn children further into rice or household production. However, children in families with small landholdings increased their supply of 
labor to the rice market. Thus, trade increased the employment opportunities for these children. Furthermore, urban households suffered a decline in real income when the price of rice rose. These families also increased the time their children spent working. It should be noted, though, that on balance, child labor declined in Vietnam following the liberalization of the rice market. A 30 percent increase in the price of rice resulted in a nine percentage point decline in child labor.

Edmonds and Pavcnik (2006) report similar results for a cross-country analysis. It appears that trade openness and child labor are negatively correlated. Each one percent increase in trade openness reduced child labor by 0.7 percent. Edmonds and Pavcnik find that the negative correlation between child labor and income is primarily driven by the positive correlation between trade openness and income growth.

Neumayer and de Soysa (2005b) extend the results of Edmonds and Pavcnik to include FDI. Not only do countries open to trade have a lower incidence of child labor, countries with a larger stock of capital also have fewer working children. Indeed, there seems to be little empirical evidence that capital owners are attracted to markets in which child labor is common. In fact, the opposite appears to be the case. Neumayer and de Soysa (2005a, 2007) find a similar conclusion when analyzing the connection between trade and gender discrimination, forced labor, free association and collective bargaining. Even in a sub-sample of developing countries, the correlation between trade/FDI openness and labor protections is either positive or zero.

Harrison and Scorse (2010) study the impact of export orientation for minimum-wage law compliance for Indonesian firms during the 1990s. Over this period, Indonesia quadrupled its minimum wage in nominal terms, resulting in a doubling of the real minimum wage. They find that foreign-owned firms were more likely to be in compliance than domestic-owned firms, 
even controlling for worker and plant characteristics. Furthermore, export-oriented firms were also more likely to be in compliance. However, Harrison and Scorse attach an important caveat to their results. Firms that were export oriented began the decade with poorer compliance performance than firms supplying the domestic market. It was not until the middle of the 1990s that export-oriented firms produced a record of compliance that exceeded that of domestic producers. The authors speculate that anti-sweatshop agitation early in the decade along with U.S. threats to retract tariff preferences under the GSP may have raised wages in export-oriented firms. That is, they find some evidence that Western buyers were sourcing from low-cost vendors paying below-market wages. Such firms may therefore have been a worthy target of human-rights activists.

Another noteworthy study is by Galli and Kucera (2004) who consider the effect of enforced rights to collective bargaining and free association on labor market organization for 14 Latin American countries during the 1990s. They are specifically trying to address the question as to whether employers will attempt to avoid recognizing these civic rights by informal employment practices. However, they find that greater recognition of labor rights is negatively correlated with informal employment. This is the case both across countries and across time. In light of the evidence that at least some labor protections increase production cost, we need to consider the possibility that in a globalizing environment, some governments may scale back labor protection in order to gain a competitive edge. This race to the bottom in labor protections lies at the heart of organized labor's objections to further trade liberalization. 


\section{Is There a Race to the Bottom?}

Some of the theoretical issues involving a race to the bottom are discussed in Martin and Maskus (2001). ${ }^{31}$ Brown, Deardorff, and Stern (1996) also discuss a number of channels through which international trade may affect incentives for labor legislation. What is especially noteworthy throughout this literature is that often trade provides incentives for a race to the top rather than the bottom.

For example, consider discrimination in employment. Martin and Maskus point out that employment discrimination against any particular group of workers is inefficient and, therefore, actually lowers productivity. So, a government looking for international competitiveness might strengthen anti-discrimination legislation. They point out that the only core-labor protections that might erode competitiveness are the rights to free association and collective bargaining that provide workers with the ability to constrain the supply of labor in the export sector.

The analytical framework used by Martin and Maskus is implemented empirically by Busse (2002), who reports that discrimination in employment against females weakens comparative advantage in unskilled-labor-intensive production as Martin and Maskus predicted. However, lax enforcement of laws regulating forced labor and child labor does, indeed, improve comparative advantage.

Brown, Deardorff, and Stern acknowledge that in some contexts labor protections such as health and safety may increase the cost of production. In a closed economy, some of these costs may be passed on to consumers, thus making them politically more palatable. But firms in a small open economy face fixed world prices. As a consequence, all of the cost of the standard will be borne by the producer. Nevertheless, even in this context, some countries will have an

\footnotetext{
${ }^{31}$ See also Maskus (1997) for an extended analysis of international trade and domestic policy regulating core labor practices.
} 
incentive to tighten standards. Such an outcome will emerge if labor standards are labor-using. Some examples of labor-using standards are restrictions on hours worked or minimum age of employment. An internationally adopted labor-using standard will contract the supply of labor on the world market. The contraction in the supply of labor in labor-abundant countries will improve their terms of trade at the expense of labor-scarce countries. As a consequence, laborabundant countries could be motivated to set labor standards both to achieve domestic objectives as well as to capture a terms-of-trade benefit.

Another consideration is raised by Rodrik (1998), who notes that trade openness may lead domestic producers to seek relief from costly labor standards. However, capital owners are not the only factor of production competing in the political arena. Workers in a globalizing economy also face more wage, price, and employment volatility. Governments may therefore be pressured to play a risk-reducing role either through expenditures or regulations. Indeed, as an historical matter, labor has typically won this contest. Huberman (2002) examines the evolution of labor protections during the first globalization century. This period is characterized by profound convergence in factor prices. One might expect therefore to observe convergence in labor-market institutions as well. However, this is not the case until the eve of WWI. For the most part, countries typically developed idiosyncratic labor protections that reflected their own particular political and social institutions.

Moreover, to the extent that standards converged, they converged up. In a companion piece, Huberman and Lewchuk (2002) note that, between 1850 and 1913, the rise in wage and employment instability that accompanied rising trade shares led workers to demand greater government protections against employment risk and uncertainty. Governments that adopted labor protections also found labor willing to support greater trade liberalization. Thus, trade 
begat labor protections and labor protections begat trade openness. Rodrik comes to the same conclusion based on analysis of data from the second half of the $20^{\text {th }}$ century. Those open economies with the largest terms-of-trade volatility also have larger governments.

An especially important race-to-the-bottom argument concerns the impact of weak labor protections on foreign direct investment (FDI). It seems intuitive that foreign capital may seek out the lowest cost and most malleable labor force. However, there is limited empirical evidence to support this line of thought. For example, Kucera (2002) finds that capital appears to be drawn to markets in which free association and collective bargaining rights are protected and child labor and discrimination in employment are prohibited. Foreign capital typically looks for stable labor markets that are not disrupted by political and labor violence. Further, foreign capital is typically not interested in working with the skill levels possessed by child labor. And, perhaps most importantly, societies that protect labor rights are more likely to enforce contracts and protect ownership rights generally. These are two features of the political environment that the foreign capital owners are seeking when searching for a location to install capital. ${ }^{32}$

Kucera’s results are confirmed by Teitlebaum (2010), using Kucera’s updated data set covering 170 countries for 1994-97 according to 37 categories of potential labor-rights violations. Teitlebaum attempts to improve upon Kucera’s judgmentally weighted measures by use of item-response theory, which is related to factor analysis and can help to understand how the component categories of labor rights relate to the underlying concept of violations of these rights. Teitlebaum finds no statistically significant relationship between labor rights and FDI and

\footnotetext{
${ }^{32}$ Moran (2011) has documented that “... by far the majority of manufacturing FDI in developing countries flows to more advanced industrial sectors rather than to garments, footwear, and other lowest-skilled operations, and the weighting toward more skill-intensive investor operations is speeding up over time." He further notes that "...survey data consistently show that foreign investors pay more than local firms...," and "[T]his process exhibits race-to-the- top dynamics quite at variance with the race-to-the-bottom assumptions in much of the sweatshop literature.”
} 
therefore evidence against the notion of race-to-the-bottom. ${ }^{33,34}$ As he states (p. 473):

“Investment is more likely to be influenced by levels of human capital, existing stocks of

investment, north-south differences, and country size than by government repression of

organized labor.”35

\begin{abstract}
${ }^{33}$ Kucera and Sarna (2006) use a gravity model covering 162 countries from 1992-99 and conclude that stronger freedom of association and collective bargaining rights and enhanced democracy rights positively impact manufacturing exports. We should note, however, that according to Aronson (2011), China may be a special case and can be characterized as a low-wage investment haven insofar as its failure to implement its domestic laws effectively may distort international trade and investment.

${ }^{34}$ Olney (2011) finds that a reduction in employment rules leads to an I ncrease especially of inflows of mobile foreign direct investment (FDI), and that countries are competitively cutting each other's employment rules. However, we find his analysis misleading. For a start, employment protection is a measure of only one specific aspect of labor standards, so one has to be careful not to make claims about lower labor standards. In the OECD countries that Olney is studying, the highest employment protection standards are in the peripheral Mediterranean countries (those with the lowest social-insurance standards). The Scandinavian countries, the UK, and Ireland have relatively low employment protection standards, and the middle European countries like France and Germany are somewhere in between. But that ranking does not correspond to their overall labor standards. If there is a correlation with FDI flows, other variables may be operative. On the competitive undercutting of standards among countries, most all the OECD countries since the 1980s have been living in the belief that more flexible labor markets are a desirable aim of policy, and most have sought to revise their employment-protection regulations accordingly. They have been responding to a common belief shared by many of their policy makers, not to competition from their neighbors. The idea that these countries - at least the bigger ones - adjust their labor standards in order to attract FDI is in our judgment not credible. Does, for example, United States do that?
\end{abstract}

Haberli, Jansen, and Monteiro (2011) conclude that a lowering of protection levels occurs especially in high-income countries stemming from regional trade agreements (RTAs) among such countries and not from RTAs involving middle-income or low-income countries. Their model is that RTAs intensify competition among regional exporters who (through unmentioned political channels) bring about a lowering of labor standards to reduce costs. In our view, this is an altogether too narrow an explanation of changes in labor standards. Their evidence of weakening labor standards between 1980 and 2005 among high-income countries is an interesting, systematic corroboration of what we already know. It is entirely consistent with the trend in macroeconomic policies toward more flexible labor markets, or, even more broadly, with the shift toward more market-oriented labor policies initiated by countries such as the United States, UK, and other high-income countries. This trend may not have much to do with RTAs. Their more legalistic analysis of the enforcement of labor provisions in RTAs is well done, but again, they may not be grasping the underlying political reality and are not asking why the provisions so far included in RTAs are so feebly enforced.

${ }^{35}$ The question arises as to whether labor standards and human rights are covered in bilateral investment treaties (BITs). According to correspondence with Ana Frischtak, a specialist in international trade law, most BITs do not cover labor standards and human rights. In the 1994 US-Model BIT, which the US uses or at least professes to use as a model for negotiations with other countries, Articles 12 and 13 cover environment and labor, respectively. The language in both Articles 12 and 13 is relatively weak. For example, Article 13 provides that:

"The Parties recognize that it is inappropriate to encourage investment by weakening or reducing the protections afforded in domestic labor laws. Accordingly, each Party shall strive to ensure that it does not 


\section{Conclusions}

Over the last three decades, the international trade community has undertaken an exhaustive and exhausting discussion as to whether access to global markets should be conditioned on an acceptable record of labor protections and human rights. As of the Singapore Ministerial (1996), weak labor protections and their accompanying human rights violations are formally excluded as a basis for restricting imports within the WTO multilateral system. The sole exception applies to goods produced by prison labor. However, trade-linked labor standards are not prohibited in preferential trading agreements as provided for in WTO Article XXIV governing the creation of customs unions and FTAs and the Enabling Clause of $1979^{36}$ governing special and differential treatment for developing country exports. While the WTO charter establishes some terms limiting the use of PTAs, there are no restrictions on conditionality relating to labor standards and enforcement. As a consequence, most current PTAs involving developed and developing countries contain labor-standards provisions. ${ }^{37}$

The pure theory of labor-standards setting establishes cross-country heterogeneity of labor law, free trade, and humanitarian transfers as the first-best policy configuration. The pure theory, however, does not address optimal international-standards setting in the presence of certain market and government failures. The most egregious government failure involves the

waive or otherwise derogate from, or offer to waive or otherwise derogate from, such laws in a manner that weakens or reduces adherence to the internationally recognized labor rights...as an encouragement for the establishment, acquisition, expansion, or retention of an investment in its territory. If a Party considers that the other Party has offered such an encouragement, it may request consultations with the other Party and the two Parties shall consult with a view to avoiding any such encouragement. "

It is unclear how such a paragraph would ever be enforced against a party and whether a party could even be found to have breached the agreement as a result of the above. It seems pretty aspirational. It remains to be determined whether and to what extent more recent U.S. and other countries' BITs are covering labor and human-rights issues. It is likely that they probably are not, but, to the extent that they are, they are most likely doing so in a relatively weak way.

${ }^{36}$ GATT Document, Differential and More Favorable Treatment, Reciprocity and Fuller Participation of Developing Countries ('Enabling Clause') (28 November 1979) L/4903 (reproduced in Annex) para 2(a).

${ }^{37}$ But, as noted earlier, the labor-standards provisions are not subject to the WTO dispute-settlement procedures. 
inability to enforce the property claim that each individual has over his or her own body, giving rise to forced labor and human trafficking. Less severe human-rights violations involve the exercise of monopsony power that occurs when governments fail to enforce labor agreements. Firms employing low-education, docile female workers with limited market experience may find that the profit-maximizing human-resource-management system consists of payment of a reservation wage, failure to pay wages as promised, excess hours of work, and verbally and physically abusive motivational techniques. Additional labor and human-rights violations as they pertain to extremely hazardous conditions of work may arise as a consequence of information asymmetries between workers and managers. Workers may only appreciate the dangers of locked exit doors and toxic materials after the dangers have been realized. As a consequence, an employer will not have a pecuniary incentive to adopt the ex post efficient configuration of workplace hazard mitigation and compensating pay differentials.

International labor standards that prohibit forced labor require the enforcement of agreed upon terms of employment and require employers to provide a safe workplace or disclose and compensate for occupational dangers that can improve market efficiency and equity in a global trading context. Basic labor protections also increase the probability that the gains from trade are not procured exclusively by employers.

The first cases of strict enforcement of trade-linked labor standards involved high stakes confrontations with nondemocratic regimes violently repressing union rights. However, standards of enforcement were inconsistently applied as developed country government objectives concerning security, business interests, and human rights came into conflict.

Since 1996, labor-standards setting and monitoring have fallen largely under the purview of the ILO, with preferential access to developed country markets the enforcement mechanism. 
Several aspects of ILO standards conform with the pure theory of international-labor-standards setting. Core standards that penalize firms engaging in forced labor address the government failures involving the protection of each individual's property right to their own body. Labor standards that focus on workplace practices and terms of employment address government failure to enforce labor contracts and informational asymmetries that produce inefficient work contracts.

However, beyond core labor protections, the ILO adopts local labor law as the reference standard. Standards pertaining to regular work hours, overtime, and compensation are determined by national labor law, thus providing the cross-country heterogeneity of standards required for economic efficiency.

There is a variety of empirical evidence available that suggests that the implementation of labor standards in practice generally has a positive effect on international trade and investment. It is also the case that that there does not appear to be a race-to-the-bottom as far as the implementation is concerned. 


\section{References}

Aidt, Toke, and Zafiris Tzannatos. 2002. Unions and Collective Bargaining: Economic Effects in a Global Environment. World Bank, Washington D.C.

Andrees, Beate, and Patrick Belser (eds.). 2009. Forced Labor: Coercion and Exploitation in the Private Economy. Boulder: Lynne Rienner Publishers.

Aronson, Susan. 2011. “How China’s Employment Problems Became Trade Problems,” in process.

Bagwell, Kyle, and Robert W. Staiger. 2001. "Domestic Policies, National Sovereignty, and International Economic Institutions.” Quarterly Journal of Economics, Vol. 116, No.2 May.

Baland, Jean-Marie, and James A. Robinson . 2000. “Is Child Labor Inefficient?” Journal of Political Economy, vol. 108 (4).

Bandiera, O., I. Barankay, and I. Rasul. 2007. "Incentives for Managers and Inequality Among Workers: Evidence from a Firm-Level Experiment,” Quarterly Journal of Economics, 122 (2), 729-773.

Bajaj http://economix.blogs.nytimes.com/2010/07/21/garment-factories-changing-womensroles-in-poor-countries/

Basu, Kaushik. 1999. “Child Labor: Causes, Consequences, and Cure, with Remarks on International Labor Standards.” Journal of Economic Literature, vol. 37.

Bhagwati, Jagdish, and T.N. Srinivasan. 2002. "Trade and Poverty in the Poor Countries.” American Economic Review Papers and Proceedings, vol. 92(2).

Black, Sandra, and Elizabeth Brainard. 2004. "Importing Equality? The Impact of Globalization on Gender Discrimination.” Industrial and Labor Relations Review, Vol. 57, No. 4.

Brown, Andrew G., and Robert M. Stern. 2008. "What Are the Issues in Using Trade Agreements to Improve Labor Standards?” World Trade Review, Vol. 7, April.

Brown, Drusilla K. 2006. "Consumer Product Labels, Child Labor and Educational Attainment," The B.E. Journal of Economic Analysis \& Policy, Berkeley Electronic Press, vol. 0(1).

Brown, Drusilla K. 2011. “Labor Standards and Human Rights,” in Amrita Narlikar, Martin Daunton, and Robert M. Stern (eds.). The Oxford Handbook on the World Trade Organization, Oxford: Oxford University Press, forthcoming.

Brown, Drusilla K., and Robert M. Stern (eds.). 2007. The WTO and Labor and Employment. Edward Elgar Publishers.

Brown, Drusilla K., Alan V. Deardorff, and Robert M. Stern. 1996 “International Labor Standards and Trade: A Theoretical Analysis,” in Jagdish N. Bhagwati and Robert E. Hudec, eds., Fair Trade and Harmonization: Prerequisites for Free Trade?, MIT Press, pp. 227-280

Brown, Drusilla K., Alan V. Deardorff, and Robert M. Stern. 2003. “Child Labor: Theory, Evidence, Policy.” In K. Basu, H. Horn, L. Roman, J. Shapiro (eds.), International Labour Standards - Issues, Theories and Policy, Basil Blackwell. 
Brown, Drusilla K., Rajiv Dehejia, and Raymond Robertson. 2010. Better Factories Cambodia, Summary of Findings, September 13.

Busse, Matthias. 2002. "Do Labor Standards Affect Comparative Advantage in Developing Countries?” World Development, 30 (11), November, 1921-32.

Busse, Matthias, and Christian Spielmann. 2006. “Gender Inequality and Trade.” Review of International Economics. Vol. 14, No. 3 (August).

Cavaglia, Chiara. 2010. Trading with the European Union: the impact of decent work in developing countries. University of Manchester.

Cling, Jean-Pierre, Mireille Razafindrakoto, and François Roubaud. 2009. “Export Processing Zones in Madagascar: The Impact of the Dismantling of Clothing Quotas on Employment and Labor Standards.” In R. Robertson, D. Brown, G. Pierre, and M. Sanchez-Puerta (eds.), Globalization, Wages, and the Quality of Jobs. The World Bank, Washington, D.C.

Compa, Lance A., and Jeffrey S. Vogt. 2001. "Labor Rights in the Generalized System of Preferences: A 20-Year Review.” Comparative Labor Law \& Policy Journal, Vol. 22, No. 199.

Edmonds, Eric. 2008. “Child Labor.” In Handbook of Development Economics, Vol. 4. T.P Schults and J. Strauss (eds.), North Holland.

Edmonds, Eric, and Nina Pavcnik. 2005a. “Child Labor in the Global Economy.” Journal of Economic Perspectives. Vol. 19.

Edmonds, Eric, and Nina Pavcnik. 2005b. “The Effect of Trade Liberalization on Child Labor.” Journal of International Economics, vol. 65.

Edmonds Eric, and Nina Pavcnik. 2006. "International Trade and Child Labor: Cross-Country Evidence.” Journal of International Economics, vol. 68.

Elliott, Kimberly Ann. 2004. “Labor Standards, Development and CAFTA,” International Economics Policy Briefs, Institute for International Economics, Center for Global Development, March, Number PB04-2.

Elliott, Kimberly Ann. 2011. “Labor Rights,” in Jean-Pierre Chauffour and Jean-Christophe Maur (eds.), Preferential Trade Agreement Policies for Development: A Handbook. Washington, D.C.: World Bank.

Elliott, Kimberly Ann, and Richard B. Freeman. 2003. "Vigilantes and Verifiers,” in Can Labor Standards Improve Under Globalization? Institute for International Relations, Washington, D.C.

Engerman, Stanley. 2003. “The History and Political Economy of International Labor Standards,” in Kaushik Basu, Henrik Horn , Lisa Roman and Judith Shapiro (eds.), International Labor Standards, Malden, MA: Blackwell Publishing Ltd., 9-83.

Falk A., E. Fehr, and C. Zehnder. 2006. “Fairness Perceptions and Reservation Wages—The Behavioral Effects of Minimum Wage Laws,” Quarterly Journal of Economics, 121 (4), 1347-1380. 
Freeman, R., and M. Kleiner. 2005. “The Last American Shoe Manufacturers: Changing the Method of Pay to Survive Foreign Competition,” Industrial Relations, 44 (2), 307-330.

Freeman, Richard, and James L. Medoff. 1984. What Do Unions Do? Basic Books, New York.

Galli, Rossana and David Kucera. 2004. "Labor Standards and Informal Employment in Latin America,” World Development, vol. 32, issue 5 (May), pp. 809-828.

Goldin, Claudia, and Lawrence Katz. 2003. "Mass Secondary Schooling and the State: The Role of State Compulsion in the High School Movement.” Working Paper No. 10075. National Bureau of Economic Research, Cambridge MA.

Haberli, Christian, Marion Jansen, and Jose-Antonio Monteiro. 2011. "References to Domestic Labor Market Regulation in Regional Trade Agreements,” NCCR Trade Working Paper no. 2010/35.

Hamilton, B., J. Nickerson, and H. Owan. 2003. “Team Incentives and Worker Heterogeneity: An Empirical Analysis of the Impact of Teams on Productivity and Participation,” Journal of Political Economy, 11 (3), 465-497.

Harrison, A. 2007. Globalization and Poverty. University of Chicago Press, Chicago.

Harrison, A. and J. Scorse. 2010. "Multinationals and Anti-Sweatshop Activism," American Economic Review 100:1, 247-73.

Hoekman, Bernard, and Çaglar Özden. 2005. “Trade Preferences and Differential Treatment of Developing Countries.” World Bank Policy Working Paper 3466 (April).

Huberman, Michael. 2002. “International Labor Standards and Market Integration Before 1913: A Race to the Top?” University of Montreal, August.

Huberman, Michael, and Wayne Lewchuk. 2002. "European Economic Integration and the Labour Compact, 1850-1913,” European Review of Economic History, 7 (1), 3-41.

Ichniowski, C., K. Shaw, and G. Prennushi. 1997. “The Effects of Human Resource Management Practices on Productivity: A Study of Steel Finishing Lines,” American Economic Review, 87 (3), 291-313.

Khosla, Nidhi. 2009. “The Ready-Made Garments Industry in Bangladesh: A Means to Reducing Gender-Based Social Exclusion of Women.” Journal of International Women Studies, vol. 11, no. 1 (November).

Krueger, Anne. 1983. Trade and Employment in Developing Countries. Vol. 3, Synthesis and Conclusions. University of Chicago Press, Chicago.

Kucera, David. 2002. “International Labour Standards and Foreign Direct Investment,” International Labour Review, 141 (1-2), 31-69.

Kucera, David, and Ritash Sarna. 2006. "Trade Union Rights, Democracy and Exports: A Gravity Model Approach,” Review of International Economics 14 (5):859-82.

Lazear, E.P., and P. Oyer. 2007 . "Personnel Economics.” National Bureau of Economic Research, Working Paper 13480.

Levinsohn, James. 1999. "Employment Responses to International Liberalization in Chile." Journal of International Economics. Vol. 47. 
Limão, Nuno. 2005. “Trade Policy, Cross-Border Externalities and Lobbies: do Linked Agreements Enforce More Cooperative Outcomes?’ Journal of International Economics, vol. 67.

Lleras-Muney, A. 2002. “Were Compulsory Attendance and Child Labor Laws Effective? An Analysis from 1915 to 1939.” Journal of Law and Economics, vol. 45.

Martin, Will, and Keith Maskus. 2001. “Core Labor Standards and Competitiveness: Implications for Global Trade Policy,” Review of International Economics, 9 (2): 317-28.

Maskus, Keith E. 1997. "Should Core Labor Standards Be Imposed Through International Trade Policy?” World Bank, Development Research Group, Washington, August.

Moborak http://www.som.yale.edu/faculty/am833/

Moran, Theodore H. 2011. Foreign Direct Investment and Development: Launching a Second Generation of Policy Research. Washington, D.C.: Peterson Institute for International Economics .

National Labor Committee. 2006. U.S.-Jordan Free Trade Agreement Descends into Human Trafficking and Involuntary Servitude, Pittsburgh, PA.

Neumayer, Eric, and Indra de Soysa. 2005a. "Globalization and the Right to Free Association and Collective Bargaining: An Empirical Analysis,” World Development 34 (1), pp. 3149.

Neumayer, Eric, and Indra de Soysa. 2005b. “Trade Openness, Foreign Direct Investment and Child Labor,” World Development, vol. 33, issue 1 (January), pp. 43-63.

Neumayer, Eric and Indra de Soysa. 2007. “Globalization, Women’s Economic Rights and Forced Labor.” World Economy, 30 (10), pp. 1510-1535

Nicita, Alessandro, and Susan Razzaz. 2003. "Who Benefits and How Much? How Gender Affects Welfare Impacts of a Booming Textile Industry.” World Bank Policy Research Working Paper 3029, April.

OECD. 1996. “Trade, Employment and Labor Standards,” A study of Core Workers’ Rights and International Trade, COM/DEELSA/TD(96)8/FINAL. Organization of Economic Cooperation and Development, Paris.

Olney, William W. 2011. “A Race to the Bottom? Employment Protection and Foreign Direct Investment,” in process, May.

O’Rourke, Dara. 2003. “Outsourcing Regulations: Analyzing Nongovernmental Systems of labor Standards and Monitoring.” Policy Studies Journal, Vol. 31, No. 1.

Oster, Emily, and M. Bryce Millett. 2010. “Do Call Centers Promote School Enrollment? Evidence from India.” NBER Working Paper No. 15922 (April).

Paul-Muzumdar, Pratima, and Anwara Begum. 2000. “The Gender Imbalances in the Export Oriented Garment Industry in Bangladesh.” Policy Research Report on Gender and Development. Working Paper 12, World Bank, Washington D.C.

Polaski, Sandra. 2004. "Protecting Labor Rights Through Trade Agreements: An Analytical Guide.” Journal of International Law and Policy. Vol. 10 No. 13. 
Polaski, Sandra. 2009. "Harnessing Global Forces to Create Decent Work in Cambodia.” International Institute for Labor Studies, Better Work, International Labor Office, Geneva.

Rawls, John. 1993. Political Liberalism. New York: Columbia University Press.

Robertson, Raymond, Drusilla Brown, Gaëlle Pierre, and María Laura Sanchez-Puerta. 2009. Globalization, Wages, and the Quality of Jobs. The World Bank, Washington, D.C.

Rodrik, Dani. 1998. “Why Do More Open Economies Have Bigger Governments?” Journal of Political Economy, 106, October, 997-1033.

Schefer, Krista Nadhakavukaren. 2005. "Stopping Trade in Conflict Diamonds: Exploring the Trade and Human Rights Interface with the WTO Waiver for the Kimberley Process.” In Human Rights and International Trade, edited by T. Cottier, J. Pauwelyn and E. Bürgi, Oxford University Press, Oxford.

Spagnolo, Giancarlo. 2001. “Issue Linkage, Credible Delegation, and Policy Cooperation.” CEPR Discussion Paper No. 2778.

Srinivasan, T.N. 1998. “Trade and Human Rights,” in Constituent Interests and U.S. Trade Policy, A.V. Deardorff and R. M. Stern (eds.), Ann Arbor: University of Michigan Press.

Stern, Robert M. 2003. “Labor Standards and Trade Agreements,” Revue d'Economie du Developpement.

Teitlebaum, Emmanuel. 2010. "Measuring Trade Union Rights through Violations Recorded in Textual Sources: An Assessment,” Political Research Quarterly, 63:461-74.

van Staveren, Irene, Diana Elson, Caren Grown, and Nilufer Cağatay (eds). 2007. The Feminist Economics of Trade. London and New York: Routledge.

Warcziarg, Romain, and Karen Horn Welch. 2008. "Trade Liberalization and Growth: New Evidence.” World Bank Economic Review Vol. 22, 2 (June).

Warren, Cael, and Raymond Robertson. 2010. "Do Wages Serve as a Compensating Differential for Adverse Non-wage Working Conditions in Cambodia's Garment Sector?" Working Paper, Macalester College.

Weil, David. 2005. "Public Enforcement/Private Monitoring: Evaluating a New Approach to Regulating the Minimum Wage.” Industrial and Labor Relations Review, 58(2), 238-257.

World Bank. 2004. “The Impact of International Trade on Gender Equality.” PremNotes, Number 86 (May). 